\title{
WORK SAFETY IN CSR STANDARDS, NORMS AND MANAGEMENT PRACTICE
}

doi: $\quad 10.2478 /$ czoto-2019-0009

Date of submission of the article to the Editor: 10/11/2018

Date of acceptance of the article by the Editor: 14/12/2018

Katarzyna Zadros - orcid id: 0000-0003-4130-5567

${ }^{1}$ Czestochowa University of Technology, Poland, katarzyna.zadros@wz.pcz.pl

\begin{abstract}
The concept of corporate social responsibility (CSR) since several dozen years has been recognized as one of the most important solutions used by companies that want to build competitive advantage through concern for economic effects, people and the environment. Important role in the management of CSR by these companies is the implementation of its standards and norm and their reporting. However, the question arises whether such activities are sufficient to actually talk about the company as a socially responsible organization. In the presented article, a broader analysis of this problem was undertaken, trying to answer what determines the company's recognition as socially responsible.
\end{abstract}

Keywords: CSR, standards, work safety, management

\section{INTRODUCTION AND LITERATURE REVIEW}

The goal of CSR is to shape business ventures in such a way as to combine them in a social, economic and ecological field. In the European Union (EU) countries, in accordance with the latest guidelines of the European Commission (EC), regarding the responsibility of enterprises for their impact on society (Commission Communication ...; Directive of the EU Parliament and Council of Europe ...).

In international practice, one can observe a threefold approach of enterprises to CSR (Bevan et al., 2004). The first one assumes the use of selected practices, legally sanctioned and regulated by law. The second acknowledges the legitimacy of socially responsible activities, but does not apply them in practice. In the third, typical for Europe, it is assumed that CSR practices are a tool for long-term commitment and systematic improvement of the company's efficiency and position on the market (Dura 2014; Czarnecka et. al., 2013).

For the implementation of CSR, the cooperation of the organization with the social environment and building a long-term relationship with stakeholders (Freeman, 1984), ethical behavior towards these stakeholders (Carroll, 1993), as well as creating and implementing strategic solutions in all its areas (Drucker, 1973). Norms and standards are used to measure the implementation of these assumptions.

The oldest norms are the "Guidelines for Multinational Enterprises" developed by the OECD experts in the 1970s and the "Tripartite Declaration of Principles for International Companies" of the ILO, updated after the end of the 20th century.

Global Compact (GC) is one of the most important global CSR initiatives. His task is to persuade companies to support, adopt and apply fundamental principles in the field 
of human rights, labor standards, environmental protection and anti-corruption (www.unglobalcompact.org) in all spheres of activity.

For European analyzes and studies on good practices, also in the area of health and safety at work, a great significance goes to the ISO 26000:2010 Guidance on Social Responsibility, which:

- contributes to sustainable development, including health and the well-being of society in the area of responsibility,

- takes into account the expectations of stakeholders,

- complies with applicable law and consistent with international standards of behavior,

- is implemented throughout the organization and practiced in its activities within its sphere of influence (International Organization for Standardization...; Zanko and Dawson, 2012).

The analysis of its guidelines allows us to assume that the occupational safety and health system can be used as a tool for implementing the principles of social responsibility in the area called "Employment Practices". Moreover, some actions and expectations have a direct reference to the areas: "Human rights", "Consumer issues" and "Environment" (Zanko and Dawson, 2012).

Supporting the implementation of CSR is also possible due to the AccountAbility AA1000 series standards (Pflugrath et al., 2010). Thanks to them, the company is equipped with methods allowing to manage engagement in relations and dialogue with stakeholders in order to build company value, stimulate its innovation, risk management as well as create corporate governance and apply modern management methods. The series has three standards:

- AA1000APS (AccountAbility Principles Standard) - responsibility rules

- AA1000SES (AccountAbility Stakeholder Engagement Standard) - stakeholder engagement

- AA1000AS (AccountAbility Assurance Standard) - verification (Fonseca, 2010; https://www.accountability.org/standards).

From the perspective of the impact of the implementation of CSR principles on safety and health at work, the SA8000:2014 standard, which is a voluntary set of rules and procedures to protect basic employee rights, is of particular importance.

It requires 8 initial conditions to be met: not employing children, not using forced labor, complying with the basic recommendations of work environment safety, observing freedom of association of employees, collective bargaining rights, non-discrimination in employment, not applying physical and mental pressure to employees, complying with legal regulations regarding time work and the right to remuneration not lower than guaranteed by law (Advisory Council ...; Social Accountability 8000).

It is a global standard, it can be used in all countries and all types of enterprises. In the case of companies in which there is a BHP system compliant with the PN-N18001 standard (OH-SAS 18001), its use is particularly easy, because this standard is much more detailed than SA8000 (Social Accountability International ...).

Summing up, the totality of reporting instruments for socially responsible practices can be divided into four categories:

1. Aspiration rules and codes of conduct.

2. Guidelines for management and certification systems.

3. Assessment indicators used by investment agencies. 
4. Reporting and communication guidelines (Makuch, 2011).

Whereas the regulations and solutions regarding health and safety and its relation to other social issues should cover at least the following categories of problems:

- Safety and health of employees.

- Human resource Management.

- Maintaining a balance between work and private life of employees.

- Issues of basic employee rights.

- Environmental protection.

- Profitability and productivity of business operations (Eccles and Krzus, 2010).

The effect of introducing norms allowing to assess the degree of CSR implementation is the process of reporting it. The most important meaning in reporting has an indicator called GRI - Global Reporting Initiative (Brown et al., 2009; Toppinen et al., 2011), developed by an independent institution, based in the Netherlands, working for the development and promotion of CSR (Sustainability Reporting Guidelines; www.globalreporting.org.pl). In 2007, GRI developed the Integrated Reporting Framework for economic, environmental and social aspects of business operations and disseminated the idea of creating integrated reports that combine the entire reporting of an organization (Sustainability Reporting...). The GRI Integrated Reporting Framework defines the Standard Information that should be included in the report and performance indicators for key areas (Global Reporting Initiative, 2013; Sustainability Reporting ...).

They also indicate 10 principles to ensure the quality of reports and comparability in the scale of individual companies in member countries and on a global scale. The rules were collected in two categories: rules for defining quality and rules for defining content. The standards also provide two levels of reporting: basic (core), meaning reporting of at least one indicator for each of the main areas, and extended (comprehensive), obliging to report all indicators (Koskela, 2014; Kudełko et. al., 2016).

Among the CSR reports used in various countries of the world and providing information on the applied solutions in the field of occupational health and safety management, the following are also applied: IFAC Sustainability Framework 2.0; ESG Framework along with KPIs for ESG; SustainAbility Global Reporters program; ISO Sustainable Development 2018, IRCSA-Framework for integrated reporting; Guidelines for the Global Reporting Initiative (GRI); or International structure of integrated reporting of the International Integrated Reporting Council (IIRC) (Carini et al., 2018).

From the point of view of Polish companies, the RESPECT Index (www.gpw.pl/ RESPECT_Index), functioning since 2009, is of significant importance in CSR reporting, along with GRI. The index includes companies that meet the requirements of the ESG group Environmental, Social and Governance, as well as corporate governance, information governance and investor relations (www2.deloitte.com/content/dam/Deloitte/pl/Documents/

Brochures/pl_Respect_Index_ulotka.pdf). Beside them, for 16 years the Responsible Business Forum has been conducting an annual report on good practices, while the CSRinfo portal collects, analyzes and stores reports sent to it. 
The information presented above is the starting point for the analysis of information on the number and content of reports in terms of the information contained in them regarding the management of occupational safety and health of employees, which will be presented in the further part of the study.

\section{METHODOLOGY}

As in many studies on the application and reporting of CSR standards, the presented study will carry out a quantitative analysis of the content presented in the CSR reports and integrated reports of Polish and international institutions collecting data on reporting in the period from 2004 to 2016.

Another source of information and data will be the analysis of reports and scientific studies prepared and presented by Polish and international institutions examining issues related to the implementation of national and international guidelines on health and safety and their use in the area of corporate social responsibility.

\section{RESULTS AND DISCUSSION}

A comparison of the norms and standards of social responsibility that can be used by enterprises and other organizations allows us to assume that every entity that implemented the SA8000 standard automatically introduces above-standard management solutions in the area of occupational health and safety, similarly in the case of organizations in which the PN-N standard applies -18001. However, the problem is to find out what number of organizations have implemented them, as in Poland and other EU countries, there is no obligation to officially inform about it. Indirectly, the scale of implementation of these standards can be assessed by analyzing the content of CSR (or sustainable development) reports and integrated reports. In the latter, obligatory solutions must be included in the area of occupational health and safety management. The beneficial changes in this area are evidenced by, among others, data included in the Safety and Health at Work SAE 2017, which shows that in comparison to 2016 there was a slight decrease in the number of work accidents in the world, from 4.3 million to 4.2 million.

Proportionally, the most information about both areas is provided by reports that meet the GRI standards. The number of organizations presenting such reports in the world (Table 1) and in Poland (Table 2) is systematically increasing.

In the case of reports registered in GRI, especially large changes concern recent years, because new EU regulations introduced from 2017 the obligatory nature of non-financial reporting for large companies and already preparing for the new situation regularly since 2015 prepare reports that meet the requirements of Directive 2014/95/EU regarding the obligation of non-financial reporting.

Table 1

Changes in the number of reports reported to GRI

\begin{tabular}{|c|l|l|}
\hline $\begin{array}{c}\text { Fiscal } \\
\text { year }\end{array}$ & \multicolumn{2}{|c|}{ Number of reports (approximate values) } \\
\cline { 2 - 3 } & Sustainable development (CSR) & \multicolumn{1}{|c|}{ Integrated reports (GRI) } \\
\hline 2004 & 2000 & 10 \\
\hline 2005 & 2300 & 10 \\
\hline 2006 & 2900 & 60 \\
\hline 2007 & 3400 & 110 \\
\hline 2008 & 4100 & 190 \\
\hline
\end{tabular}




\begin{tabular}{|l|l|l|}
\hline 2009 & 4900 & 240 \\
\hline 2010 & 5800 & 275 \\
\hline 2011 & 5900 & 360 \\
\hline 2012 & 6200 & 375 \\
\hline 2013 & 6900 & 410 \\
\hline 2014 & 12700 & 1450 \\
\hline 2015 & 41600 & 27300 \\
\hline 2016 & 50500 & 31000 \\
\hline
\end{tabular}

Source: Own elaboration based on data: globalreporting.org.

The smaller companies do similarly, although reporting is not compulsory for them. In this way, they probably try to stand out on the market while building a competitive advantage.

In the case of Poland, such a rapid increase in the number of integrated reports is not visible, as the largest companies have been presenting such reports for several years now.

Table 2

Changes in the number of reports registered in CSRinfo

\begin{tabular}{|c|l|l|}
\hline $\begin{array}{c}\text { Fiscal } \\
\text { year }\end{array}$ & \multicolumn{2}{|c|}{ Number of reports (approximate values) } \\
\cline { 2 - 3 } & Sustainable development (CSR) & Integrated reports (GRI) \\
\hline 2004 & 0 & 0 \\
\hline 2005 & 1 & 0 \\
\hline 2006 & 4 & 0 \\
\hline 2007 & 3 & 1 \\
\hline 2008 & 15 & 1 \\
\hline 2009 & 13 & 4 \\
\hline 2010 & 29 & 12 \\
\hline 2011 & 37 & 18 \\
\hline 2012 & 41 & 28 \\
\hline 2013 & 49 & 22 \\
\hline 2014 & 40 & 20 \\
\hline 2015 & 55 & 28 \\
\hline 2016 & 41 & 31 \\
\hline
\end{tabular}

Source: Own study based on data: CSRinfo.pl.

Problems with the assessment of the actual level of involvement in the implementation of CSR activities, including the area of occupational safety and health, concern the initiatives reported to the Global Compact. This is due to the constantly growing number of companies applying to it, as in 2013 it was over 10,000 business organizations, and in 2017 13,500, which makes it impossible to say whether all information contained in the reports sent to it are true and reliable. It is only possible to assess whether the content of the reports complies with the requirements. Analysts and researchers estimate that a large proportion of companies use GC reporting for image building, conducting activities referred to as greenwashing, consisting of faking CSR activities for financial gain (Voegtlin and Pless, 2014).

Research on the implementation of CSR principles by enterprises in areas related to health and safety at work is carried out by numerous European and national institutions. The European Foundation for Improvement of Living and Working Conditions belongs to their group, the analysis of which shows that in the EU 
countries the most important impact on the implementation of health and safety tasks by the company has binding legal regulations. Increasingly, however, such activities are undertaken to increase the efficiency and quality of production, create a positive image of the company, and increase employee involvement (https://www.eurofo und.europa.eu/en/topic/working-conditions-and-sustainable-work). However, among managers, the view prevails that providing employees with safe and healthy working conditions is only an additional cost, not a tangible benefit.

This approach practically prevents the actual implementation of CSR assumptions, while the European Agency for Safety and Health at Work (EU-OSHA) takes the position that occupational protection is one of the integral elements of the CSR concept, and employees are key stakeholders of each organization (https://osha.europa.eu/tools-and-publications/publications). This statement is supported by the results of national and international surveys, which show that CSR reporting companies are strictly complying with standards and standards, including health and safety, than required by law (Carrots, Stics, 2013).

When analyzing the impact of the implementation of the CSR concept on the safety and health of employees, attention should also be paid to the results of research carried out under the multi-annual program "Improving safety and working conditions", showing the beneficial impact of implementing CSR principles in the area of occupational safety and health management, especially quality improvement life at work and reducing the sickness absence of employees of Polish enterprises (https://m.ciop.pl/CIOPPortalWAR/appmanager/ciop/pl).

Research conducted in Poland and other European countries shows that companies that undertake activities in the area of CSR in such a way as to increase employee safety and job satisfaction, are better at overcoming problems and are better perceived by external stakeholders (Krainz, 2015). As shown by the research carried out by Deloitte in 2016, they also have the opportunity to recruit the most talented employees, and consumers are more and more willing to choose brands that are perceived as socially responsible (https://www2.deloitte.com/pl/pl/pl/pages/pressrelasses/articles/purpose-2030-good-business- and-better).

\section{CONCLUSION}

Contemporary companies applying CSR principles have enormous opportunities to report good practices in all areas of their activity, including occupational health and safety.

The analysis carried out in the article shows that more and more companies are reporting socially responsible practices, including those related to occupational health and safety. However, it should be stated that although the number of reported practices in this area is systematically growing, they are still much less than in other, more visible for the environment of the organization.

While analyzing the issues of implementing CSR standards (including those covering good practices in the field of occupational safety and health care) and reporting, it should be remembered that despite many methods, techniques and measurement tools available for companies and organizations recommended by national institutions and international, one commonly accepted and fully objective CSR meter has still not been developed. Already in 1973, R.N. Farmer and W. Dickerson-Hogue stated that, unlike the possibility of measuring the degree of implementation of the adopted economic goals, there is no recognized method for measuring the effectiveness of 
socially responsible activities (Farmer, Dickerson-Hogue, 1973) and this statement even today has not lost its relevance.

\section{REFERENCES}

Basu, K., Palazzo, G., 2008. Corporate Social Responsibility: a process model of sensemaking, Academy of Management Review, 33(1), 124, DOI:10.5465/amr.2008.27745504.

Bevan, S., Isles, N., Emery, P., Hoskins, T., 2004. Achieving high performance. CSR at the heart of business, The Work Foundation, The Virtuous Circle, London.

BHPSustainabilityReport2017.pdf, http://BHPSustainabilityReport2017.pdf (15.11.2018).

Carini, C., Rocca, L., Veneziani, M., Teodori, C., 2018. Ex-Ante Impact Assessment of Sustainability Information - The Directive 2014/95, Sustainability, 10, 560, DOI:10.3390/su10020560.

Carroll, A.B., 1993. Business and Society: Ethics and Stakeholders Management, College-Division South-Western Publishing Co, Cincinnati, Ohio.

Communication from the Commission to the European Parliament, the Council, the European Economic and Social Committee and the Committee of the Regions a renewed EU strategy 2011-14 for Corporate Social Responsibility, Brussels 2011, (http://eur-lex.europa.eu, 16.11.2018).

Czarnecka, A., Robak, E., Słocińska, A., 2013. Rola związków zawodowych w kreowaniu CSR, Związki zawodowe w procesie przemian społecznogospodarczych w Polsce i wybranych krajach Unii Europejskiej, ed. M. Bsoul, F. Bylok, Wyd. Naukowe Śląsk, Katowice.

Debeljak, J., Krkac, K., Bus`ljeta, Banks, I., 2011. Acquiring CSR practices: from deception to authenticity, Social Responsibility Journal, (7)1, 5-22, DOI: 10.1108/17471111111114503.

Directive 2014/95/Eu of the European Parliament and of the Council of 22 October 2014 amending Directive 2013/34/EU as regards disclosure of non-financial and diversity information by certain large undertakings and groups, OJ L 330 .

Drucker, P.F., 1973. Management Task, Responsibilities, Practices, Harper\&Row, New York.

Dura, C., 2014. Occupational Health And Safety Integration In Corporate Social Responsibility Policies Within B.R.D. - G.S.G, Romania Annals of the University of Petroşani, Economics, (14)1, 59-70.

Eccles, R.G., Krzus, M.P., 2010. One Report. Integrated Reporting for a Sustainable Strategy, John Wiley \& Sons, Inc., New Jersey, 10-11.

Farmer, R.N., Dickerson-Hogue, W., 1973. Corporate Social Responsibility, Science Research Associates, Chicago.

Fonseca, A., 2010. How credible are mining corporations' sustainability reports? a critical analysis of external assurance under the requirements of the international council on mining and metals, Corporate Social Responsibility Environment Management, (17)6, 355-370, DOI:10.1002/csr.230.

Freeman, E.R., 1984. Strategic Management. A Stakeholder Approach, Pitman, Boston.

Global Reporting Initiative, 2013. G4 Sustainability Reporting Guidelines, Amsterdam.

Guidance on social responsibility (ISO 26000:2010). International Organization for Standardization (https://www.iso.org/standard/42546.html). 
International Standard by Social Accountability International, June 2014, p. 4, http://www.sa-intl.org/_data/global/files/SA8000 Standard2014(3).pdf.

ISO 26000. Społeczna odpowiedzialność, http://www.pkn.pl.sistes/default/files/ discovering_iso_26000.pdf (15.11.2018).

Koskela, M., 2014. Occupational health and safety in corporate social responsibility reports, Safety Science, 68, 294-308, DOI:10.1016/j.ssci.2014.04.011.

Krainz, K.D., 2015. Enhancing wellbeing of employees through Corporate social responsibility context, Megatrend Review, (12)2, 137-152.

Kudełko, J., Hop, N., Kozłowska-Pęciak, W., Bachowski, C., 2016. Raportowanie Społecznej Odpowiedzialności Biznesu w przemyśle wydobywczym według wytycznych Global Reporting Initiative, Nauki o Zarządzaniu (3)28, Uniwersytet Ekonomiczny, Wrocław, 72-92, DOI: 10.15611/noz.2016.3.06.

Makuch, Ł., 2011. Normy i standardy społecznej odpowiedzialności biznesu (CSR), Wyższa Szkoła Pedagogiczna TPW, Warszawa.

Pflugrath, G., Roebuck, P., Simnett, R., 2011. Impact of Assurance and Assurer's Professional Affiliation on Financial Analysts' Assessment of Credibility of Corporate Social Responsibility Information, Journal of Practice \& Theory, (30)3, 239-254, DOI:10.2308/ajpt-10047.

Social Accountability International. Council on Economic Priorities Accreditation Agency, www.sa-intl.org (10.11.2018).

Social Accountability International. Social Accountability 8000 (SA8000:2001).

Sustainability reporting guidelines on economic, environmental, and social performance. Version 3.1., 2000-2011, Global Reporting Initiative.

Toppinen, A., Li N., Tuppura, A., Xiong, Y., 2011. Corporate responsibility and strategic groups in the forest-based industry: exploratory analysis based on the Global Reporting Initiative (GRI) framework. Corporate Social Responsibility Environment Management, (19)4, 191-205, DOI:10.1002/csr.256.

Voegtlin, C., Pless, N.M., 2014. Global Governance: CSR and the Role of the UN Global Compact, Journal of Business Ethics, (122)2, 181-182, DOI: 10.1007/s10551-014-2214-8.

Zanko, M., Dawson, P., 2012. Occupational health and safety Management in Organizations. International Journal of Management Review, 14, 328-344, DOI: 10.1111/j.1468-2370.2011.00319.x.

https://www.accountability.org/standards (21.11.2018).

https://www2.deloitte.com/pl/pl/pages/press-relasses/articles/purpose-2030-good-

business-and-better (12.11.2018).

http://www2.deloitte.com/content/dam/Deloitte/pl/Documents/Brochures/pl_Respect_I ndex_ulotka.pdf (12.11.2018).

http://www.gpw.pl/RESPECT_Index (15.11.2018).

http://gf24.pl/indeks-spolecznej-odpowiedzialnosci/ (12.11.2018).

https://www.globalreporting.org.pl (10.11.2018).

https://www.unglobalcompact.org (10.11.2018).

https://www.eurofound.europa.eu/pl/topic/working-conditions-and-sustainable-work

(15.11.2018).

https://osha.europa.eu/tools-and-publications/publications (15.11.2018).

https://m.ciop.pl/CIOPPortalWAR/appmanager/ciop/pl (12.11.2018). 